\title{
Analisa Pengaruh Kecepatan Kendaraan terhadap Tingkat Kebisingan yang Terjadi pada Ruas Jalan dengan Perkerasan Kaku
}

\author{
Syahlendra Syahrul ${ }^{1, a}$ dan Aisyah Zakaria ${ }^{1, b}$ \\ ${ }^{1}$ Politeknik Negeri Ujung Pandang, Jalan Perintis Kemerdekaan KM.10 Tamalanrea, Makassar 90245, Indonesia \\ baisyahzakaria_78@yahoo.com \\ asyahlendrassyahrul@poliupg.ac.id
}

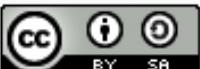

\begin{abstract}
Along with the increasing needs of people in Makassar city for the mode of transportation, the number of the growth of motor vehicles that operate on the road becomes larger than the growth of the number of roads built. This has caused some problems in the transportation sector. In addition to congestion problems, problems arise from road surface damage due to increasing traffic loads that must be borne by the road surface. To anticipate this, some strategic streets in the city of Makassar then designed by using a rigid pavement that has greater strength in carrying the burden. Another problem that arises from the growing number of motor vehicles that operate on the road is greater than the growth of the number of roads built is the higher levels of noise pollution or traffic noise. Noise is sourced from the sound of a vehicle engine and the friction between the vehicle tire and the road surface. So that roads with rigid surface pavement surfaces that have a rougher surface texture, potentially lead to higher noise levels. This study aims to determine how much noise levels that occur in roads that use rigid pavement in the city of Makassar. The road segments, such as Jl. Abd. Dg. Sirua, Jl. Batua Raya and Jl. Adhyaksa. The tool used to measure traffic noise is the Sound Level Meter (SLM). The survey was conducted for 1 day for each of the road segments reviewed. The data taken are the level data of flatness of road surface, vehicle speed data and traffic noise level data. Data processing is done by analyzing the relationship between the factors that affect the noise with the noise level that occurs on the road with rigid pavement. The results of this study are expected to provide information about how big the effect of vehicle speed on the noise level that arises on the road with rigid pavement.
\end{abstract}

Keyword--Noise; speed of vehicle; Rigid Pavement

Abstrak - Seiring dengan semakin meningkatnya kebutuhan masyarakat di kota Makassar akan moda transportasi, pertumbuhan jumlah kendaraan bermotor yang beroprasi di jalan menjadi lebih besar dibanding pertumbuhan jumlah jalan yang dibangun. Hal tersebut menimbulkan beberapa masalah pada sektor transportasi. Selain masalah kemacetan, masalah juga timbul dari kerusakan permukaan jalan akibat semakin bertambahnya beban laluintas yang harus dipikul oleh permukaan jalan. Untuk mengantisipasi hal tersebut, beberapa ruas jalan strategis di kota makassar kemudian dirancang dengan menggunakan perkerasan kaku yang memiliki kekuatan lebih besar dalam memikul beban. Masalah lain yang muncul akibat pertumbuhan jumlah kendaraan bermotor yang beroprasi di jalan lebih besar dibanding pertumbuhan jumlah jalan yang dibangun adalah semakin tingginya tingkat polusi suara atau kebisingan lalulintas. Kebisingan bersumber dari bunyi mesin kendaraan dan gesekan antara ban kendaraan dengan permukaan jalan. Sehingga jalan dengan lapis permukaan perkerasan kaku yang memiliki tekstur permukaan lebih kasar, berpotensi menimbulkan tingkat kebisingan yang lebih tinggi. Penelitian ini bertujuan untuk mengetahui seberapa besar tingkat kebisingan yang terjadi di ruas jalan yang menggunakan perkerasan kaku di kota Makassar. Ruas jalan yang ditinjau antara lain Jl. Abd. Dg. Sirua, Jl. Batua Raya dan Jl. Adhyaksa. Alat yang digunakan untuk mengukur kebisingan lalulintas adalah Sound Level Meter (SLM). Survey dilakukan selama 1 hari untuk masing-masing ruas jalan yang ditinjau. Data yang diambil adalah data tingkat kerataan permukaan jalan, data kecepatan kendaraan dan data tingkat kebisingan lalulintas. Pengolahan data dilakukan dengan menganalisa hubungan antara faktor-faktor yang mempengaruhi kebisingan dengan tingkat kebisingan yang terjadi pada ruas jalan dengan perkerasan kaku. Hasil penelitian diharapkan dapat memberikan informasi tentang seberapa besar pengaruh kecepatan kendaraan terhadap tingkat kebisingan yang timbul pada ruas jalan dengan perkerasan kaku.

Kata Kunci-Kebisingan; kecepatan kendaraan; Perkerasan Kaku

\section{Pendahuluan}

Salah satu penyebab permasalahan transportasi di Kota Makassar adalah pertumbuhan kendaraan yang begitu pesat. Dari penelitian terdahulu diketahui bahwa pada tahun 2012, tercatat pertumbuhan kendaraan 
bermotor di Kota Makassar sebesar 12\%, sedangkan pembangunan dan pertumbuhan prasarana jalan baru sebesar kurang dari 3\% per tahun [1]. Angka tersebut menunjukkan pertumbuhan kendaraan tidak sebanding dengan peningkatan jaringan jalan, dimana hal ini tentu saja menimbulkan masalah di ruas jalan Kota Makassar.

Terdapat beberapa macam masalah yang dapat ditimbulkan dari tidak sebandingnya pertumbuhan jumlah kendaraan bermotor dengan pertumbuhan sarana jalan yang dibangun. Selain masalah kemacetan dan kerusakan permukaan jalan, masalah lain yang ditimbulkan di bidang transportasi adalah masalah lingkungan seperti kebisingan atau polusi suara [2].

Setiap kendaraan bermotor yang beroperasi dijalan menghasilkan kebisingan, terdapat 2 sumber utama yang mempengaruhi kebisingan yang ditimbulkan oleh kendaraan bermotor, sumber tersebut antara lain suara mesin kendaraan dan interaksi antara roda kendaraan dan permukaan jalan [3]. Besarnya kebisingan dipengaruhi oleh kondisi lalulintas (kecepatan kendaraan dan volume lalulintas), faktor lain yang bisa mempengaruhi kebisingan adalah bunyi klakson kendaraan [1]. Peningkatan kebisingan secara bertahap akan mengurangi kualitas kesehatan lingkungan sehingga kegiatan dasar masyarakat seperti tidur, istirahat, belajar dan berkomunikasi menjadi terganggu [4].

Kota Makassar sebagai salah satu kota besar di Indonesia juga memiliki Masalah kebisingan. Dari hasil penelitian terdahulu diketahui bahwa tingkat kebisingan yang ada di ruas jalan protokol wilayah kota Makassar sudah mencapai $74 \mathrm{~dB}$ [1], nilai tersebut telah melebihi standar baku mutu yang berlaku. Penelitian tersebut dilakukan di ruas-ruas jalan protokol Kota Makassar, akan tetapi belum meninjau pada ruas jalan protokol berdasarkan jenis permukaan jalan yang digunakan, apakah menggunakan perkerasan lentur (Flexible Pavement), menggunakan perkerasan kaku (rigid pavement), ataukah menggunakan perkerasan komposit (Composit Pavement).

Perkerasan kaku dirancang untuk mengantisipasi beban lalu lintas yang berat, hal ini dilakukan sebagai salah satu upaya untuk mengantisipasi masalah kerusakan permukaan jalan yang ditimbulkan karena tidak sebandingnya pertumbuhan jalan dengan pertumbuhan jumlah kendaraan bermotor yang beroprasi. Masalah lain kemudian timbul karena perkerasan kaku memiliki tekstur permukaan yang lebih kasar dibandingkan perkerasan lentur. tekstur permukaan jalan merupakan faktor yang sangat penting dalam perambatan bising dari kendaraan ketika kendaraan bergerak pada kecepatan lebih dari $40 \mathrm{~km} / \mathrm{jam}$ [3].

Berdasarkan uraian di atas, dirasakan perlu untuk merancang suatu penelitian yang menganalisa kebisingan yang timbul pada ruas Jalan yang menggunakan perkerasan kaku (rigid pavement), terutama pada ruas jalan yang padat pemukiman penduduk. Beberapa ruas jalan yang menggunakan perkerasan kaku di Kota Makassar teridentifikasi secara visual memiliki lalulintas yang padat dan lingkungan yang padat penduduk. Jalan-jalan tersebut diantaranya Jl. Abd. Dg. Sirua, Jl. Batua Raya dan Jl. Adhyaksa. Untuk itu dirasakan perlu untuk menganalisa tingkat kebisingan pada ke 3 ruas jalan tersebut karena kebisingan yang terjadi berpotensi menganggu penduduk sekitar.

Hasil penelitian diharapkan bisa memberikan informasi tentang seberapa besar pengaruh kecepatan kendaraan terhadap tingkat kebisingan yang terjadi pada ruas jalan yang ditinjau, sehingga jika misalnya diketahui tingkat kebisingan yang terjadi melebihi ambang batas yang diizinkan, kemudian berikutnya dapat dilakukan tindakan lanjutan untuk meredam kebisingan yang terjadi.

\section{Metode Penelitian}

\section{A. Lokasi Penelitian}

Penelitian ini dilakukan pada ruas jalan yang menggunakan perkerasan kaku di kota makassar. Ruas jalan yang ditinjau adalah Jl. Abd. Dg. Sirua, Jl. Batua Raya dan Jl. Adhyaksa.

\section{B. Bagan Alir Penelitian}

Bagan alir Penelitian ini secara garis besar dilakukan dengan beberapa tahapan yang dapat dilihat pada Gambar 1. 


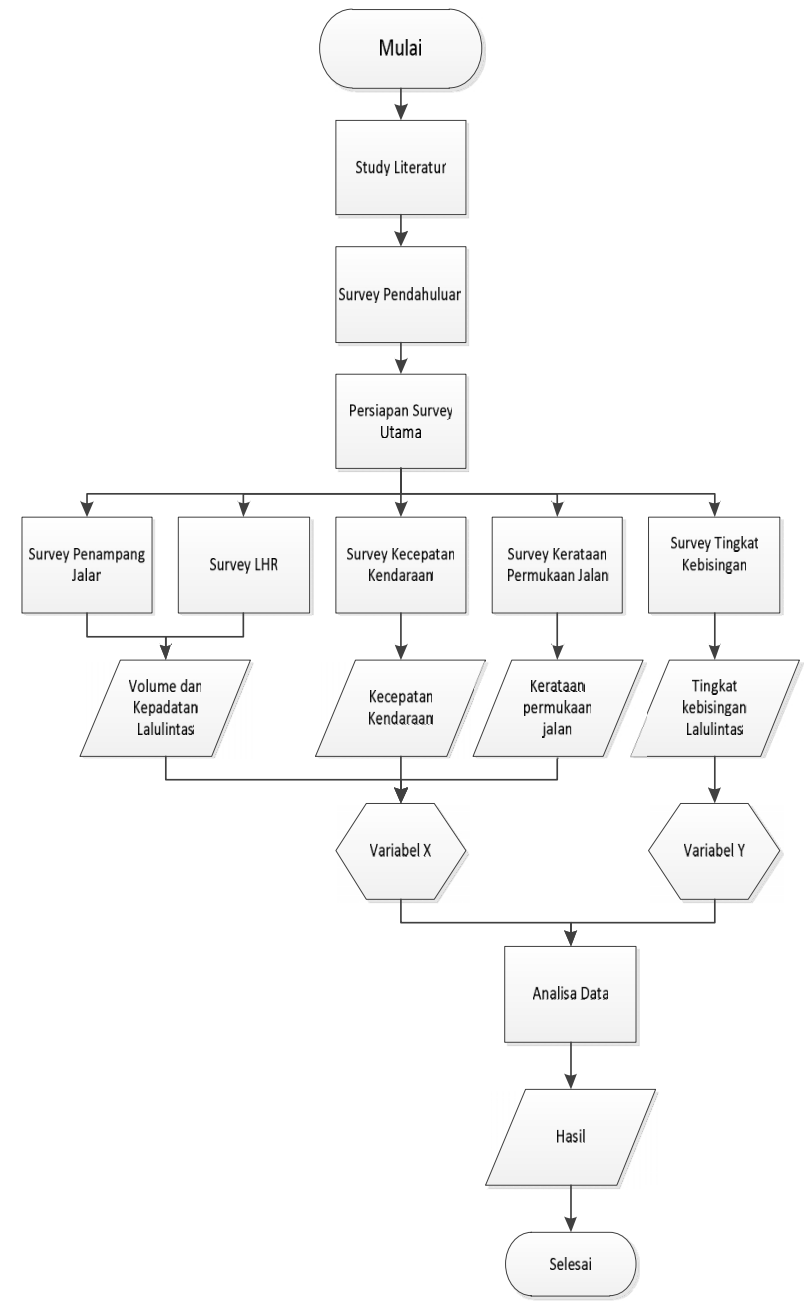

Gambar 1. Tahapan Penelitian

\section{Rancangan Penelitian}

Penelitian ini dirancang menjadi penelitian kuantitatif, data yang diperlukan dalam penelitian ini adalah data tingkat kebisingan lalulintas, data kecepatan kendaraan, dan data tingkat ketidakrataan permukaan jalan. Penelitian dilakukan pada 3 ruas jalan yang menggunakan perkerasan kaku di kota makassar. Ruas jalan yang ditinjau adalah Jl. Abd. Dg. Sirua, Jl. Batua Raya dan Jl. Adhyaksa.

Data yang diperoleh kemudian dikumpulkan, setelah itu ditetapkan jenis variabelnya untuk pengolahan lanjutan. Penelitian ini menghasilkan nilai kebisingan yang timbul pada perkerasan kaku pada ruas jalan yang ditinjau. Penelitian ini juga direncanakan menghasilkan model hubungan antara kecepatan kendaraan dengan tingkat kebisingan yang terjadi pada perkerasan kaku.

\section{Metode Pengambilan Data}

Data yang diambil dalam penelitian ini adalah data tingkat kebisingan lalulintas, data kecepatan kendaraan, dan data tingkat kerataan permukaan jalan.

Untuk data tingkat kebisingan lalulintas, metode pengambilannya dilakukan dengan cara pengukuran secara langsung menggunakan alat Sound Level Meter (SLM) tiap ruas jalan yang ditinjau.

Untuk data kecepatan kendaraan, metode pengambilannya juga dilakukan dengan cara pengukuran secara langsung menggunakan Speed Gun. Direncanakan akan dilakukan pengambilan beberapa sampel kecepatan kendaraan untuk tiap type kendaraan.

Penelitian ini dirancang menjadi penelitian kuantitatif, data yang diperlukan dalam penelitian ini adalah data tingkat kebisingan lalulintas, data kecepatan kendaraan, dan data tingkat ketidakrataan permukaan jalan. Penelitian dilakukan pada 3 ruas jalan yang menggunakan perkerasan kaku di kota makassar. Ruas jalan yang ditinjau adalah Jl. Abd. Dg. Sirua, Jl. Batua Raya dan J1. Adhyaksa.

\section{E. Analisa Data}

Untuk data primer utama seperti tingkat kebisingan dan kecepatan kendaraan hasilnya diperoleh secara langsung dari hasil survey.

Data yang dianalisa adalah data hubungan faktorfaktor yang mempengaruhi tingkat kebisingan dengan besarnya tingkat kebisingan. Data dianalisa dengan teknik statistik regresi linear seara manual ataupun dengan menggunakan bantuan prangkat lunak (Software) pengolahan statistik.

\section{Hasil dan Pembahasan}

\section{A. Pengukuran Tingkat Kebisingan}

Kondisi pengukuran kebisingan selama penelitian berlangsung berjalan normal, tidak ada gangguan yang dapat menambah nilai tingkat. Cuaca pada saat pengukuran dalam keadaan cerah. Ruas jalan merupakan kawasan perdagangan dan jasa. Adapun grafik tingkat kebisingan ketiga ruas jalan yang ditinjau dapat dilihat pada Gambar 2. 


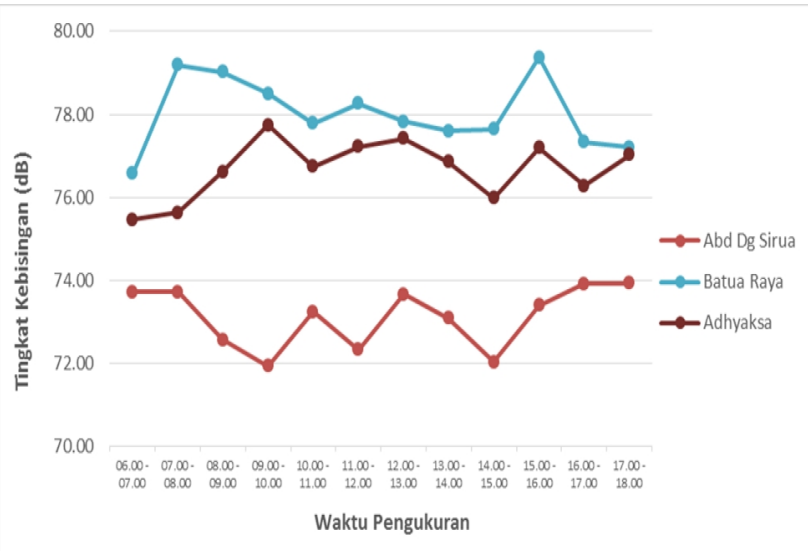

Gambar 2. Hasil Pengukuran Kebisingan Kendaraan

Berdasarkan gambar 2 diatas, dapat dilihat bahwa pada ruas jalan Abd. Dg. Sirua, Leq yang didapatkan untuk setiap jamnya selama 12 jam diatas $70 \mathrm{~dB}$, dimana pada pukul 07.00-08.00, memiliki tingkat kebisingan yang paling tinggi dari jam-jam yang lain yaitu $73,73 \mathrm{~dB}$ dan pada pukul 09.00-10.00 memiliki tingkat kebisingan yang paling rendah yaitu $71.95 \mathrm{~dB}$. Hal ini terjadi dikarenakan aktifitas disekitar ruas jalan Abdullah Dg. Sirua yang padat. Aktifitas ini berupa bengkel, pertokoan dan restauran yang hampir dapat ditemukan disepanjang jalan. Selain itu akses kendaraan dari jalan AP. Pettrani juga menjadi penyebab padatnya lalu lintas. Dari analisa data yang dilakukan, didapatkan nilai Leqday dengan tingkat kebisingan yang diperoleh untuk lokasi penelitian Jalan Abdullah Dg. Sirua adalah 73.19 dBA yang berarti sudah melebihi sedikit dari Standar Baku Mutu Tingkat Kebisingan berdasarkan KepMenLH nomor 48 Tahun 1996 untuk kawasan perdagangan dan jasa yang hanya $70 \mathrm{~dB}$.

Untuk ruas jalan Batua Raya dapat dilihat bahwa Leq yang didapatkan untuk setiap jamnya selama 12 jam diatas $75 \mathrm{~dB}$, dimana pada pukul 15.00 - 16.00, memiliki tingkat kebisingan yang paling tinggi dari jamjam yang lain yaitu 79,38 dB dan pada pukul 06.0007.00 memiliki tingkat kebisingan yang paling rendah yaitu 76,58 dB. Hal ini terjadi dikarenakan banyaknya kendaraan berat yang melalui ruas jalan tersebut. Kendaraan berat tersebut merupakan truk sampah dari Jalan Antang yang mengambil akses menuju perkotaan. Dari analisa data yang dilakukan, didapatkan nilai Leqday dengan tingkat kebisingan yang diperoleh untuk lokasi penelitian Jalan Batua Raya adalah 78,11 dB(A) yang berarti sudah melewati Standar Baku Mutu Tingkat Kebisingan berdasarkan KepMenLH nomor 48 Tahun 1996 untuk kawasan perdagangan dan jasa yang hanya $70 \mathrm{~dB}$.

Untuk ruas jalan Adhyaksa, dapat dilihat bahwa Leq yang didapatkan untuk setiap jamnya selama 12 jam diatas $70 \mathrm{~dB}$ dimana pada pukul 09.00-10.00, memiliki tingkat kebisingan yang paling tinggi dari jam-jam yang lain yaitu $77,75 \mathrm{~dB}$ dan pada pukul 06.00-07.00 memiliki tingkat kebisingan yang paling rendah yaitu $75.46 \mathrm{~dB}$. Hal ini terjadi dikarenakan jalan Adyaksa merupakan satu-satunya akses menuju pusat perbelanjaan dan perhotelan yaitu Mall Panakukkang, Hotel Swiss belinn dan Hotel Myko. Dari analisa data yang dilakukan, didapatkan Leq day dengan tingkat kebisingan yang diperoleh untuk lokasi penelitian Jalan Adhyaksa adalah 76.74 dBA yang berarti sudah melewati Standar Baku Mutu Tingkat Kebisingan berdasarkan KepMenLH nomor 48 Tahun 1996 untuk kawasan perdagangan dan jasa yang hanya $70 \mathrm{~dB}$.

\section{B. Pengukuran Kecepatan Kendaraan}

Gambar 3 menunjukkan hasil pengukuran kecepatan kendaraan yang dilakukan.

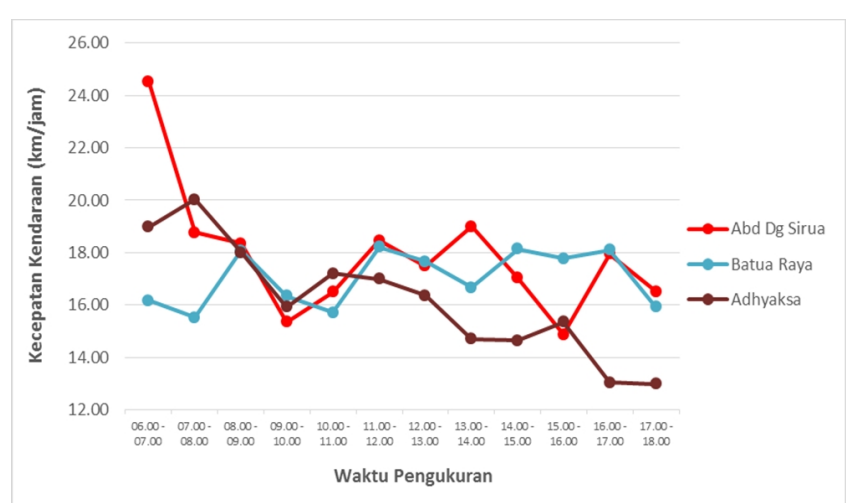

Gambar 3. Hasil Pengukuran Kecepatan Kendaraan

Gambar 3 menunjukkan hasil pengukuran kecepatan kendaraan, dimana kecepatan kendaraan tertinggi pada ruas jalan abd dg. Sirua terjadi pada pukul $06.00-07.00$ yaitu sebesar 24,5 km/jam dan kecepatan kendaraan terendah terjadi pada pukul 15.00 - 16.00 yaitu sebesar $14,9 \mathrm{~km} / \mathrm{jam}$. Dari analisa data yang dilakukan, diperoleh kecepatan rata-rata untuk ruas jalan Abd Dg. Sirua yaitu sebesar $17,9 \mathrm{~km} / \mathrm{jam}$. Hal ini terjadi dikarenakan ruas 
jalan Abdullah Dg. Sirua selain merupakan daerah pemukiman juga merupakan daerah dengan aktifitas kegiatan berupa bengkel, pertokoan dan restauran yang hampir dapat ditemukan disepanjang jalan. Hal tersebut mengakibatkan kecepatan tertinggi terjadi pada saat aktifitas bengkel dan pertokoan belum buka yaitu pada pukul 06.00 - 07.00 dan kecepatan kendaraan terendah terjadi pada pukul 15.00 - 16.00 pada saat aktifitas bengkel dan pertokoan sedang ramai serta arus pulang karyawan dari kantor menuju pemukiman di kawasan jalan Abdullah Dg. Sirua juga sudah mulai ramai. Untuk ruas jalan Batua Raya, kecepatan kendaraan tertinggi terjadi pada pukul 11.00 - 12.00 yaitu sebesar 18,2 $\mathrm{km} / \mathrm{jam}$ dan kecepatan kendaraan terendah terjadi pada pukul 07.00 - 08.00 yaitu sebesar $15,5 \mathrm{~km} / \mathrm{jam}$. Dari analisa data yang dilakukan, diperoleh kecepatan ratarata untuk ruas jalan Batua Raya yaitu sebesar 17 $\mathrm{km} / \mathrm{jam}$. Hal ini terjadi dikarenakan ruas jalan Batua Raya selain merupakan daerah pemukiman juga merupakan daerah dengan aktifitas kegiatan berupa bengkel, pertokoan, restaurant dan sekolah. Lalu lintas jalan pada ruas jalan ini juga sangat dipengaruhi oleh aktifitas sekolah yaitu SMPN 8 Makassar. Hal tersebut mengakibatkan kecepatan tertinggi terjadi pada saat aktifitas sekolah tidak ramai yaitu pada pukul 11.00 12.00 dan kecepatan kendaraan terendah terjadi pada pukul 07.00 - 08.00 pada saat aktifitas sekolah sedang ramai karena arus kedatangan siswa sekolah.

Untuk ruas jalan Adhyaksa, kecepatan kendaraan tertinggi terjadi pada pukul $07.00-08.00$ yaitu sebesar $20 \mathrm{~km} / \mathrm{jam}$ dan kecepatan kendaraan terendah terjadi pada pukul 17.00 - 18.00 yaitu sebesar $13 \mathrm{~km} / \mathrm{jam}$. Dari analisa data yang dilakukan, diperoleh kecepatan ratarata untuk ruas jalan Adhyaksa yaitu sebesar 16,2 $\mathrm{km} / \mathrm{jam}$. Hal ini terjadi dikarenakan ruas jalan Adhyaksa selain merupakan daerah dengan aktifitas kegiatan berupa pemukiman, pertokoan dan pusat perbelanjaan. Hal tersebut mengakibatkan kecepatan tertinggi terjadi pada saat aktifitas pertokoan dan pusat perbelanjaan belum buka yaitu pada pukul 07.00 - 08.00 dan kecepatan kendaraan terendah terjadi pada pukul $17.00-$ 18.00 pada saat aktifitas pertokoan dan pusat perbelanjaan sedang ramai serta arus pulang karyawan dari kantor menuju pemukiman di kawasan jalan Adhyaksa juga sudah mulai ramai.

\section{Hubungan Kecepatan Kendaraan dengan Kebisingan Lalulintas}

Hubungan kecepatan kendaraan dengan kebisingan lalulintas dianalisa dengan model regresi linear untuk melihat hubungan langsung antara kecepatan kendaraan dengan kebisingan lalulintas, serta untuk melihat logical test dari model yang dihasilkan. Gambar 4. menunjukkan hubungan antara kebisingan lalulintas dengan kecepatan kendaraan pada ruas jalan Abd. Dg. Sirua.

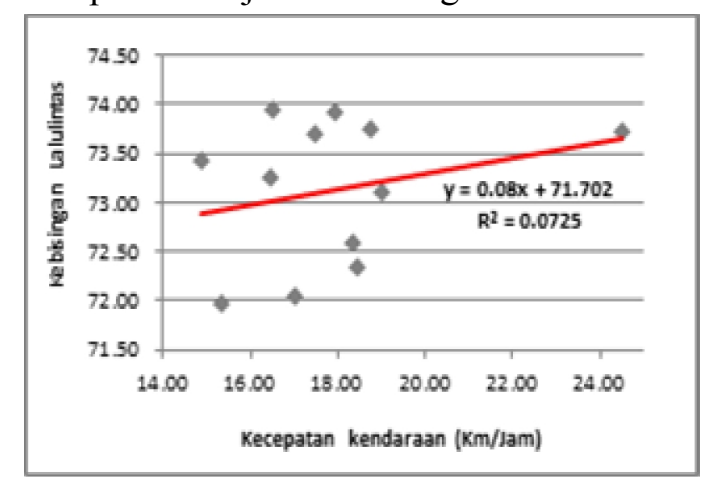

Gambar 4. Hubungan Kebisingan dengan Kecepatan Kendaraan pada ruas jalan Abd. Dg. Sirua

Dari gambar 4, diketahui model yang dihasilkan yaitu $y=0,08 x+71,702$, dimana $R^{2}=0,0725$. Model ini memperlihatkan nilai yang sesuai dengan logical test, dimana semakin tinggi tingkat kecepatan kendaraan, semakin tinggi pula tingkat kebisingan yang dihasilkan. Model ini juga menunjukkan bahwa kecepatan kendaraan tidak begitu mempengaruhi tingkat kebisingan yang terjadi, hal tersebut diperlihatkan dari koefisien variable $\mathrm{X}$ (Kebisingan) pada model yang dihasilkan sangat kecil yaitu $0,08 \mathrm{x}$, hal ini juga menunjukkan ada variable lain yang jauh lebih berpengaruh dalam menghasilkan kebisingan di ruas jalan Abd. Dg. Sirua. Gambar 5. menunjukkan hubungan antara kebisingan lalulintas dengan kecepatan kendaraan pada ruas jalan Batua Raya.

Dari gambar 5 diketahui model yang dihasilkan yaitu $\mathrm{y}=0,1305 \mathrm{x}+75,805$, dimana $\mathrm{R}^{2}=0,0258$. Model ini memperlihatkan nilai yang sesuai dengan logical test, dimana semakin tinggi tingkat kecepatan kendaraan, semakin tinggi pula tingkat kebisingan yang dihasilkan. Model ini juga menunjukkan bahwa kecepatan kendaraan tidak begitu mempengaruhi tingkat kebisingan yang terjadi, hal tersebut diperlihatkan dari koefisien variable $\mathrm{X}$ (Kebisingan) pada model yang 
dihasilkan sangat kecil yaitu $0,1305 x$, hal ini juga menunjukkan ada variable lain yang jauh lebih berpengaruh dalam menghasilkan kebisingan di ruas jalan Batua Raya.

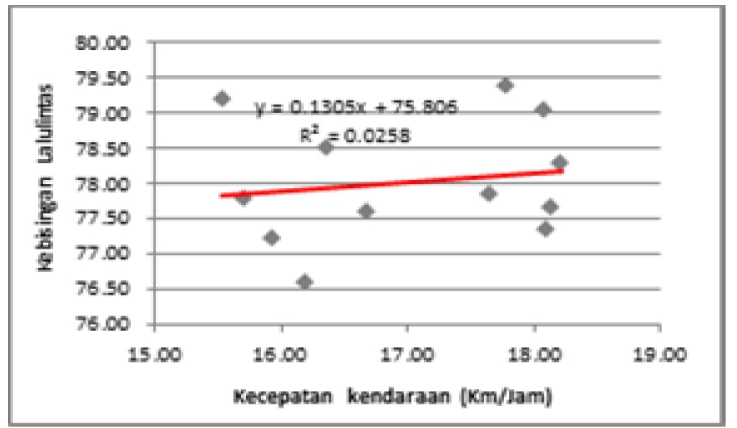

Gambar 5. Hubungan Kebisingan dengan Kecepatan Kendaraan pada ruas jalan Batua Raya

Gambar 6 menunjukkan hubungan antara kebisingan lalulintas dengan kecepatan kendaraan pada ruas jalan Adhyaksa.

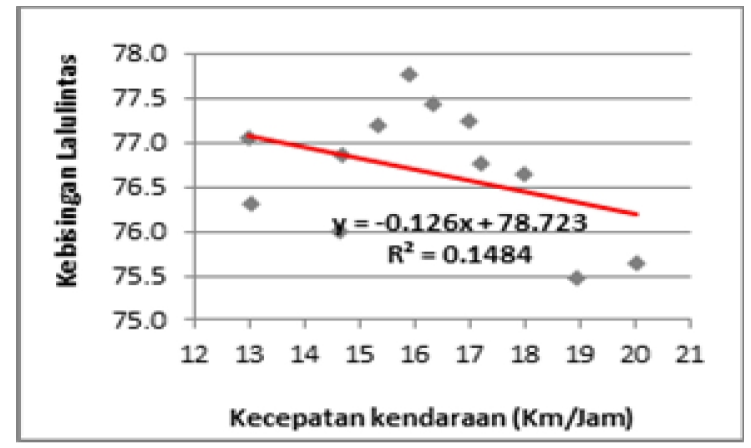

Gambar 6. Hubungan Kebisingan dengan Kecepatan Kendaraan pada ruas jalan Adhyaksa

Dari gambar 6 diketahui model yang dihasilkan yaitu $\mathrm{y}=-0,126 \mathrm{x}+78,723$, dimana $\mathrm{R}^{2}=0,1484$. Model ini memperlihatkan nilai yang berlawanan dengan logical test, dimana semakin tinggi tingkat kecepatan kendaraan, semakin rendah tingkat kebisingan yang dihasilkan. Model ini juga menunjukkan bahwa kecepatan kendaraan tidak begitu mempengaruhi tingkat kebisingan yang terjadi, hal tersebut diperlihatkan dari koefisien variable $\mathrm{X}$ (Kebisingan) pada model yang dihasilkan sangat kecil yaitu -0,126x, hal ini juga menunjukkan ada variable lain yang jauh lebih berpengaruh dalam menghasilkan kebisingan di ruas jalan Adhyaksa.

\section{Kesimpulan}

Nilai Leqday dengan tingkat kebisingan yang diperoleh untuk lokasi penelitian Jalan Abdullah Dg. Sirua adalah 73.19 dBA. Nilai Leqday dengan tingkat kebisingan yang diperoleh untuk lokasi penelitian Jalan Batua Raya adalah 78,11 dBA dan untuk nilai Leq day dengan tingkat kebisingan yang diperoleh untuk lokasi penelitian Jalan Adhyaksa adalah 76.74 dBA. Semua nilai tingkat kebisingan yang diperoleh sudah melewati Standar Baku Mutu Tingkat Kebisingan berdasarkan KepMenLH nomor 48 Tahun 1996 untuk kawasan perdagangan dan jasa yang hanya $70 \mathrm{~dB}$. Kecepatan ratarata untuk ruas jalan Abd Dg. Sirua yaitu sebesar 17,9 $\mathrm{km} / \mathrm{jam}$. Kecepatan rata-rata untuk ruas jalan Batua Raya yaitu sebesar $17 \mathrm{~km} / \mathrm{jam}$. kecepatan rata-rata untuk ruas jalan Adhyaksa yaitu sebesar 16,2 km/jam

\section{Ucapan Terima Kasih}

Terima kasih penulis ucapkan kepada Kementrian Riset Teknologi dan Pendidikan Tinggi sebagai pemberi hibah dana penelitian serta kepada berbagai pihak yang telah membantu dalam menyelesaikan penelitian ini.

\section{Daftar Pustaka}

[1] Alimuddin, 2016, Analisis Tingkat Kebisingan Simpang Empat Bersinyal Di Jalan Cendrawasih Makassar, Skripsi Tidak Diterbitkan, Makassar: Jurusan Teknik Sipil Universitas Hasanuddin

[2] Kementerian Lingkungan Hidup Republik Indonesia,1996, Keputusan Menteri Lingkungan Hidup Nomor 48 Tahun 1996 Tentang Baku Mutu Tingkat Kebisingan.

[3] Edward, J. S., 2002, Evaluasi Kebisingan Lalu Lintas Akibat Pengaruh Kekasaran Permukaan Jalan Pada Perkerasan Kaku Di Jalan Tol Padalarang - Cileunyi, Tesis Magister Jurusan Teknik Sipil Bidang Khusus Rekayasa Transportasi Program Pascasarjana Institut Teknologi Bandung 2002.

[4] Tanvir, M, and Rahman, M. M. 2011. Development of Interruped Flow Traffic Noise Prediction Model for Dhaka City. Prociding on 4th Annual Paper Meet and 1st civilEngineering Congress Dhaka, Bangladesh chap 131-138. 